(1996)

10. Butler, J.S. Trends Cell Biol. 12, 90-96 (2002)

11. Van Hoof, A. \& Parker, R. Cell 99, 347-350 (1999)

12. Bousquet-Antonelli, C., Presutti, C. \& Tollervey, D. Cell 102, 765-775 (2000).

13. Torchet, C., Bousquet-Antonelli, C., Milligan, L., Thompson, E., Kufel, J. \& Tollervey, D. Mol. Cell 9, 1285-1296 (2002).
14. Proudfoot, N.J., Furger, A. \& Dye, M.J. Cell 108 501-512 (2002)

15. Lei, E.P. \& Silver, P.A. Genes Dev. 16, 2761-2766 (2002)

16. Gatfield, D. et al. Curr. Biol. 11, 1716-1721 (2001).

17. Le Hir, H., Gatfield, D., Izaurralde, E. \& Moore, M. EMBO J. 20, 4987-4997 (2001).

18. Luo, M.L. et al. Nature 413, 644-647 (2001).
19. Rodrigues, J.P., Rode, M. Gatfield, D., Blencowe, B.J., Carmo-Fonseca, M. \& Izaurralde, E. Proc. Nath. Acad. Sci. USA 98, 1030-1035 (2001).

20. Dower, K. \& Rosbash, M. RNA 8, 686-697 (2002)

21. Manley, J.L. Nat. Struct. Biol. 9, 790-791 (2002).

22. Kwek, K.Y. et al. Nat. Struct. Biol. 9, 800-805 (2002).

23. Chavez, S., Garcia-Rubio, M., Prado, F. \& Aguilera, A. Mol. Cell. Biol. 21, 7054-7064 (2001).

\title{
From an armadillo to electricity
}

Electricity drives more than just engines. It is primarily a fundamental feature of life. From single cell organisms to neurons, electrical gradients are used to store energy chemically (as in nucleotide triphosphates, NTPs) or to generate ion fluxes, thus allowing extracellular signals to rapidly transfer from one part of our body (or cell) to another. $\mathrm{Ca}^{2+}$ ions play an important role in these forms of cellular signaling and in regulating thousands of downstream targets. One of the molecules that links $\mathrm{Ca}^{2+}$ to the function of NTPs in the transduction of extracellular signals, such as growth factors and neurotransmitters, is the intracellular messenger inositol 1,4,5-triphosphate ( $\left.\operatorname{InsP}_{3}\right)$. Generated by the enzymatic action of an activated phospholipase on a precursor, $\mathrm{InsP}_{3}$ regulates the release of intracellular $\mathrm{Ca}^{2+}$ stores by binding the $\mathrm{InsP}_{3}$ receptor on the surface of the endoplasmic reticulum (ER). Despites decades of research on the ligand and its receptor, a structure had remained elusive.

In a recent issue of Nature, Bosanac et al. (Nature 420, 696-700; 2002) report the crystal structure of a fragment of the Ins $\mathrm{P}_{3}$ receptor corresponding to the Ins $P_{3}$-binding domain. The 381-residue ligand-binding domain is located toward the $\mathrm{N}$ terminus of the protein and constitutes a small portion of the 2,749-residue $\operatorname{lns}_{3}$ receptor. Other structural elements in the receptor moderate the signal transduction process, form a channel for $\mathrm{Ca}^{2+}$ release from the $E R$ and reduce InsP $\mathrm{P}_{3}$ binding affinity from $\sim 90 \mathrm{pM}$ to $\sim 45 \mathrm{nM}$. The structure of the high-affinity, core Ins $\mathrm{P}_{3}$-binding domain in complex with $\operatorname{InsP}_{3}$ is bipartite (pink and

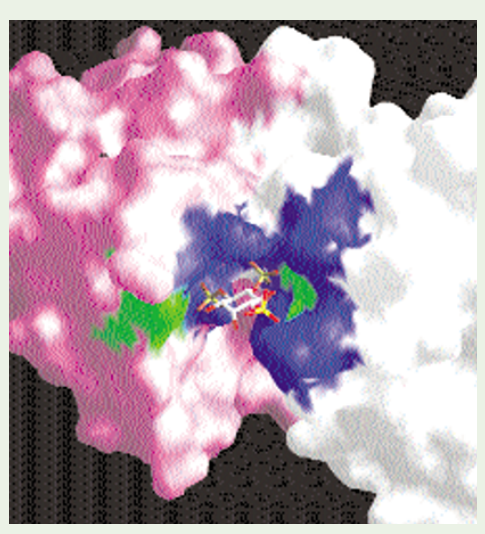

Nine Arg/Lys residues (blue) coordinate the $\operatorname{InsP}_{3}$ ligand and mediate critical interdomain interactions in the white surface), with an N-terminal region consisting of $12 \beta$-strands and 2 short helices and a C-terminal domain with $8 \alpha$-helices. Structural comparisons reveal that the $\mathrm{N}$-terminal region adopts the $\beta$-trefoil fold (pink), found in some interleukins and in FGF, whereas the C-terminal domain displays high homology to the armadillo repeat (white) of $\beta$-catenin and importin, among others. At the interface of the armadillo and $\beta$-trefoil folds lies an $\mathrm{InsP}_{3}$-binding cleft lined with basic residues (blue). The conformation of the $\operatorname{InsP}_{3}$ molecule (stick model) differs in other phosphoinositide-binding proteins, such as the pleckstrin homology and Tubby domains, suggesting that this ligand can be recognized differently. repeat InsP $\mathrm{P}_{3}$-binding domain. Receptor binding map to two distinct positions on the domain. The authors hypothesize that the binding of $\operatorname{InsP}_{3}$ to the receptor may facilitate $\mathrm{Ca}^{2+}$ binding by relieving the inhibitory function of its $\mathrm{N}$-terminal suppression domain.

This study represents an important milestone in our understanding of these key signal transduction molecules. What it does not yet reveal is precisely how $\operatorname{lnsP}_{3}$ causes $\mathrm{Ca}^{2+}$ to be released and how ligand binding in the $\mathrm{InsP}_{3}$ receptor appears to be regulated by other receptor domains. No doubt, these questions will soon be answered and increase our molecular understanding of this crucial electrical switch. Andreas G. Ladurner point mutations that eliminate $\mathrm{Ca}^{2+}$ 